\title{
POŠTA
}

TELEKOMUNIKÁCIE A

ELEKTRONICKY OBCHOD

\section{VÝZNAM INTERNEJ KOMUNIKÁCIE VO VYBRANOM POŠTOVOM PODNIKU}

\author{
Mariana Strenitzerová ${ }^{1}$
}

\section{Úvod}

Nezabúdajte - vzt’ahy so zamestnancami sú kl'účom $\mathrm{k}$ vášmu úspechu - práve tí vám $\mathrm{k}$ nemu pomáhajú. Komunikácia a vzt’ahy so zamestnancami si získavajú v Slovenskej republike pozíciu uznávanej a nepodceňovanej oblasti Public Relations. Prispieva k tomu aj množstvo udalostí, ako sú zmeny vlastníkov podnikov, fúzie, reštrukturalizácie či prepúšt’anie, o ktorých by mali byt' zamestnanci informovaní. To všetko sú udalosti, ktoré pri nekvalitnej komunikácii vedenia spoločnosti so zamestnancami môžu priniest' medzi zamestnancov neistotu, obavy a rivalitu. Každá firma však potrebuje k svojmu úspešnému fungovaniu aj lojalitu a záujem zamestnancov. Podl'a údajov Opinion Research Corp., zarad’uje vo vyspelých krajinách vedenie spoločností komunikáciu so zamestnancami hned' na druhé miesto v dôležitosti za vzt’ahy s investormi [3].

\section{Podstata a význam internej komunikácie}

Interná komunikácia je dôležitým nástrojom podnikovej kultúry a nástrojom objasňovania firemných hodnôt. Je jedným zo základných nástrojov manažmentu a má vel'ký vplyv na spoluprácu a angažovanost' pracovníkov vo firme. Môže prebiehat' medzi nadriadenými a podriadenými, manažmentom a vlastníkmi, spolupracovníkmi, jednotlivými útvarmi či organizačnými jednotkami. Interná komunikácia $\mathrm{v}$ podstate znamená komunikačné prepojenie útvarov firmy, ktoré umožňuje spoluprácu a koordináciu procesov pre fungovanie firmy [1].

Komunikácia so zamestnancami má za ciel' vybudovat' a sústavne udržiavat' vzájomne výhodné, dobré vzt’ahy medzi organizáciou, firmou, podnikom a zamestnancami, od ktorých závisí úspech aj neúspech spoločného úsilia.

Pri výbere vhodnej komunikačnej formy je dôležité uvedomit' si, či sa jedná o štandardnú situáciu alebo sa rieši úplne nový problém. Ďalším dôležitým aspektom je aj to, s kým sa manažér chystá komunikovat', nie pri každom totiž môže použit' ten istý spôsob vysielania informácií. V súčasnej dobe patri k najpoužívanejším prostriedkom internej komunikácie napríklad rozhovor, porada, diskusia, telefonický hovor, firemná tabul'a, podnikový časopis, komunikácia prostredníctvom výpočtovej techniky, dotazníkové prieskumy, schránky s odkazmi od zamestnancov, nástenky, informačné tabule a mnohé d'alšie. Čím viac týchto prostriedkov je využívaných, tým efektívnejšiu internú komunikáciu si podnik buduje. Z toho dôvodu môžeme usúdit', že „stavebným kameňom“ každej úspešnej

\footnotetext{
${ }^{1}$ doc. Ing. Mariana Strenitzerová, PhD., Žilinská Univerzita v Žiline, Fakulta prevádzky a ekonomiky dopravy a spojov, Katedra spojov, Univerzitná 1, 01026 Žilina, Slovenská republika tel. 00421-041-5133 131, fax 00421-041-5655 615, e-mail: Mariana.Strenitzerova@fpedas.uniza.sk
} 
firmy sú zamestnanci, ktorých dostatočná informovanost', angažovanost' a motivácia tvoria základný predpoklad úspešnosti a prosperity organizácie [2].

\section{Strategic Communication Management Summit 2012, Londýn}

V októbri 2012 sa v Londýne uskutočnil 11. ročník prestížneho podujatia z oblasti internej komunikácie Strategic Communication Summit, ktorý organizuje výskumnovzdelávací inštitút Melcrum. Program bol zameraný na zvýšenie významu internej komunikácie v podnikoch 21. storočia [4].

Podniky začali doceňovat' význam internej komunikácie až po prepuknutí krízy v roku 2008. Úlohou internej komunikácie v dnešnej dobe je pomáhat' implementovat' podnikové sociálne médiá, pochopit' l'udí a prepájat' ich do sietí komunít, zvyšovat' úroveň spolupráce medzi jednotlivcami, tímami a celými oddeleniami. Dôležitou témou, ktorá je rovnako skloňovaná v mnohých smeroch tak u nás ako aj v západných krajinách, ostáva návratnost' investícií do internej komunikácie. Mnohí manažéri si nevedia celkom dobre predstavit', aký prospech bude mat' pre firmu efektívne využívanie internej komunikácie a jej implementovanie do rozhodovacích procesov, preto sú v tejto oblasti skeptický.

Summitu sa zúčastnilo vyše 300 delegátov z celého sveta, z ktorých najväčšie zastúpenie mali práve interní komunikátori zo Západnej Európy. Na konferencii sa mali možnost' všetci zúčastnení interaktívne zapojit' do hlasovania na rôzne otázky, týkajúce sa internej komunikácie. Jednou z mnohých bola napríklad otázka „Do ktorej oblasti týkajúcej sa internej komunikácie Vaša organizácia plánuje najväčšiu investíciu budúci rok?“(obr. 1).

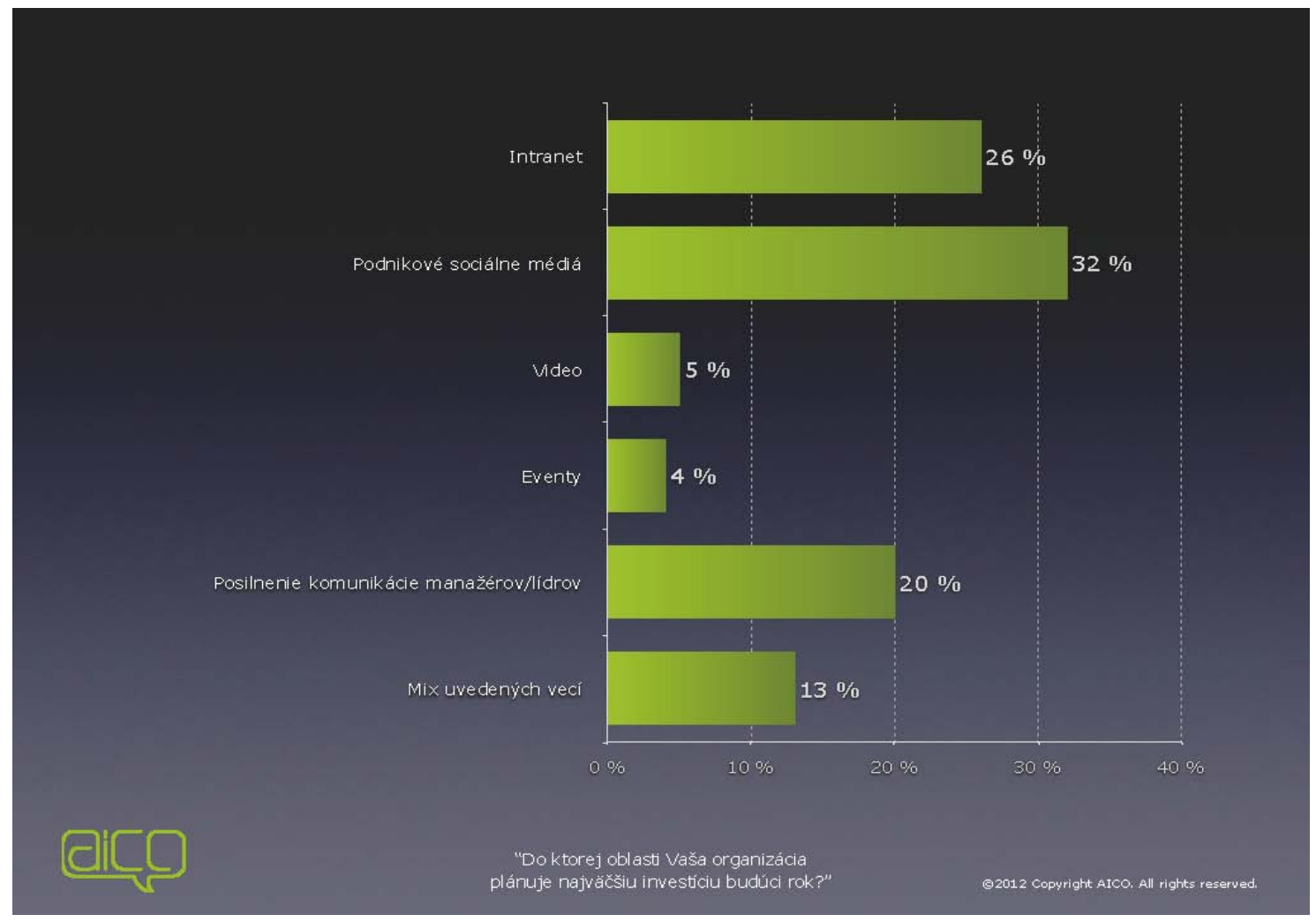

Obr. 1 Investície do IK v roku 2013

Zdroj http://www.aico.sk/sk/novinky/strategic-communication-management-summit-2012-londyn 
Z grafu vyplýva, že rastie záujem o investovanie do sociálnych médií a intranetu a posilnenie komunikácie manažérov. Informačno-komunikačné technológie hýbu svetom a odzrkadl'uje sa to aj na preferenciách podnikov.

Zaujímavé boli aj zistenia, ktoré vyplynuli z otázky zameranej na prekážky v implementovaní internej komunikácie. Až 32 \% opýtaných nemá jasne definovanú stratégiu a d'alších $30 \%$ má obmedzený rozpočet, z čoho vyplýva fakt, že na rozvoj internej komunikácie nedisponuje dostatočnými finančnými zdrojmi. Tu nastáva klasický scenár mnohých firiem. Aj ked' si uvedomujú potrebu rozvoja a implementácie internej komunikácie, svoje vol'né finančné zdroje radšej investujú do oblastí, ktoré musia prioritne riešit' a interná komunikácia ostane znova v úzadí (obr. 2).

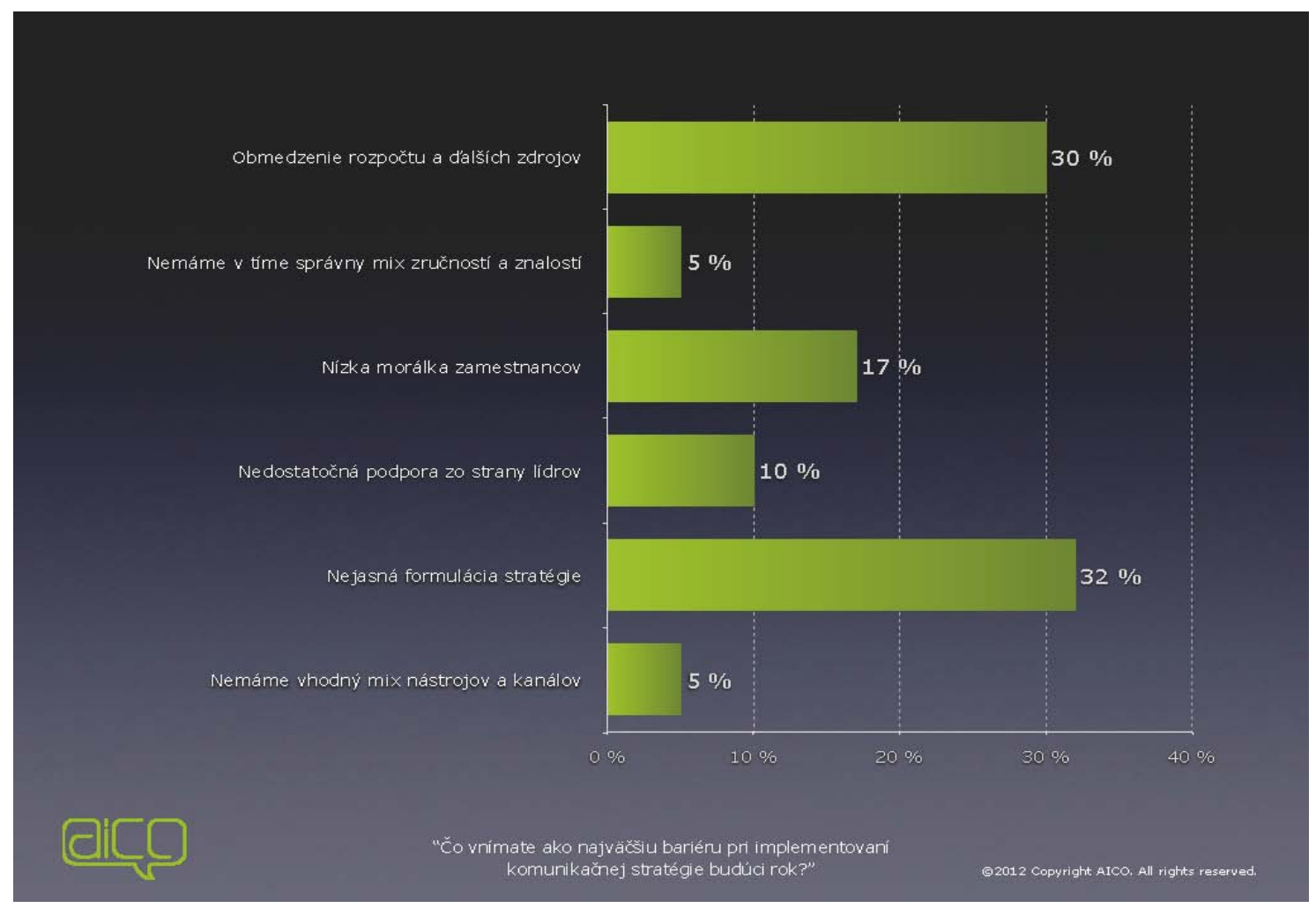

Obr. 2 Prekážky v implementovaní IK

Zdroj: http://www.aico.sk/sk/novinky/strategic-communication-management-summit-2012-londyn

\section{Interná komunikácia z pohl’adu Slovenskej republiky}

$\mathrm{Na}$ Slovensku sa pojem internej komunikácie spája predovšetkým s vel’kými korporáciami, prípadne s podnikmi, ktoré zamestnávajú viac ako 250 osôb. Aj ked' sa to môže zdat' zvláštne, interná komunikácia je jedným z klúčových faktorov úspechu firmy a vo vel'kej miere sa taktiež podiel'a na celkovej reputácii firmy. Prieskum úrovne internej komunikácie, ktorý zrealizovala nezisková organizácia AICO (The Association for Internal Communications) preukázal, že 97 \% respondentov je presvedčených, že interná komunikácia má zásadný vplyv na výkonnost' zamestnancov. Z prieskumu d’alej vyplynulo, že interná komunikácia nie je implementovaná v 33 \% slovenských podnikov, v 5 \% má interná komunikácia svoje samostatné oddelenie a v 25 \% je zahrnutá do oddelenia Human Resources (obr. 3) [5]. 


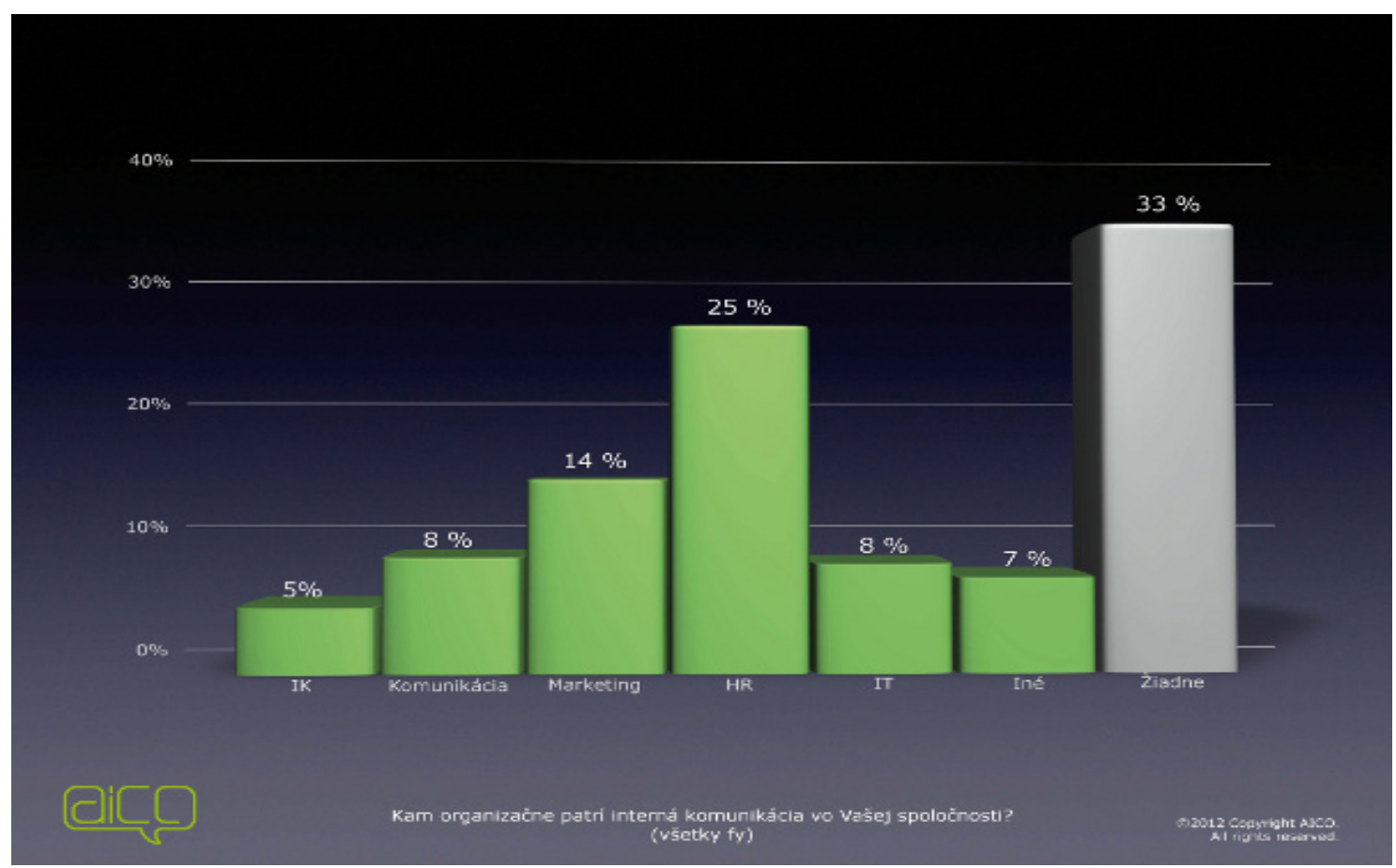

Obr. 3 Zaradenie IK v slovenských podnikoch

Zdroj: http://karierainfo.zoznam.sk/cl/1000160/1325016/Interna-komunikacia-na-Slovensku-je-vplienkach

Z uvedeného výskumu môžeme vyvodit' záver, že vzhl'adom na zvyšujúcu sa potrebu rozvíjat' vo firme internú komunikáciu, je tento pojem na slovenskom trhu ešte stále vel'kou neznámou. Dôvodom, prečo sa vo väčšine slovenských firiem nevenuje pozornost' práve internej komunikácii, je nedostatočný počet pracovníkov, nesprávne nastavené firemné procesy, nízka podpora manažmentu a samozrejme chýbajúci čas.

Čo chýba internej komunikácii na Slovensku? Na túto otázku môžeme odpovedat' vel'mi jednoducho. V slovenských firmách chýbajú tímy, ktoré by medzi sebou úzko komunikovali. Omnoho jednoduchšie je totiž poslat' e-mail a čakat', kedy za nás problém vyriešia iní. Jedna z najväčších IT spoločností ATOS chce poukázat', že pre internú komunikáciu je efektívnejšie využívat' iné kanály ako práve spomínané e-maily. Ich štatistika im totiž priniesla zistenie, že iba 15 \% prijatých e-mailov za deň bolo aj skutočne užitočných. Zamestnanci si tak začali uvedomovat', že majú k dispozícii aj iné, omnoho efektívnejšie komunikačné nástroje (obr. 4) [5]. 


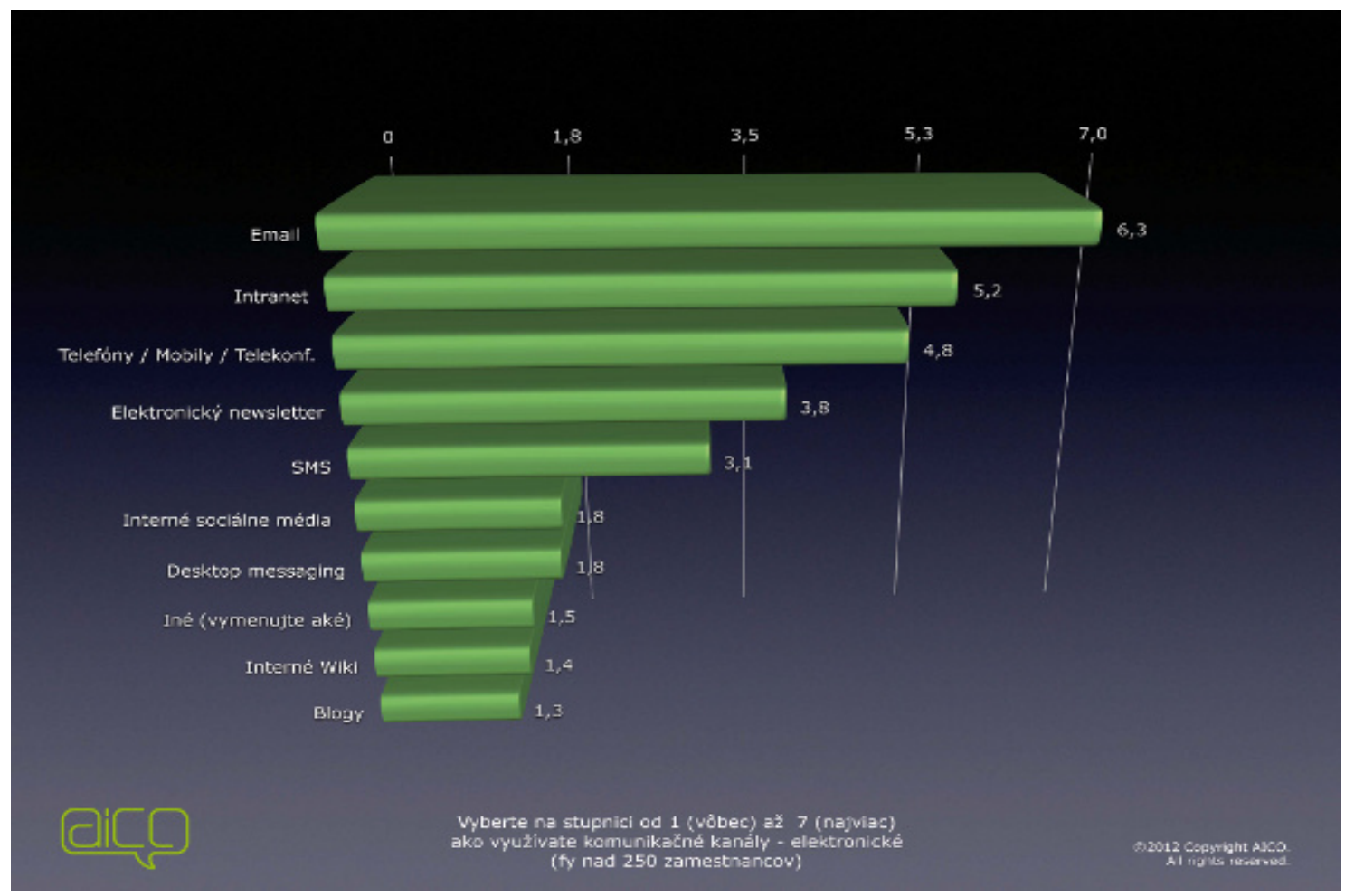

Obr. 4 Najvyužívanejšie elektronické komunikačné kanály

Zdroj: http://karierainfo.zoznam.sk/cl/1000160/1325016/Interna-komunikacia-na-Slovensku-je-vplienkach

\section{Audit internej komunikácie vo vybranom poštovom podniku}

Ako už bolo spomínané, interná komunikácia má vel'ký význam práve vo vel'kých siet'ových podnikoch, ktoré zamestnávajú niekol'ko desiatok tisíc zamestnancov. Vybraný poštový podnik v roku 2011 zamestnával 14240 zamestnancov v priemernom prepočítanom počte, preto kvalitná interná komunikácia je základom úspešného fungovania tejto spoločnosti.

Audit internej komunikácie vo vybranom poštovom podniku uskutočnila spoločnost' AMI communications, ktorá je v súčasnosti tret'ou najväčšou agentúrou PR na Slovensku. V oblasti internej komunikácie ponúka celý rad postupov a nástrojov Public Relations, ktoré dokážu zlepšit' vzt’ahy so zamestnancami - road show vedení firiem, zamestnanecké časopisy a príležitostné publikácie, intranety, pravidelné hot-lines alebo chaty so zástupcami vedenia, motivačné sút’aže, komunikačné poznávacie programy pre pracovníkov fúzujucich firiem, programy mimoprávnych aktivít a pod.

Audit internej komunikácie vo vybranom poštovom podniku bol uskutočnený na základe písomného a elektronického dotazníkového prieskumu, do ktorého bolo pozvaných 2300 zamestnancov poštového podniku. So vstupnými informáciami pomohli agentúre oddelenia personalistiky a internej komunikácie. Podl'a dohody vybrali vhodných zamestnancov a zabezpečili distribúciu dotazníkov, ako aj informácií o prieskume zodpovedným zamestnancom. 
Účastníci dotazníkového dopytovania boli vybraní z radov zamestnancov pôsobiacich $\mathrm{v}$ rôznych organizačných zložkách podniku, najmä na úseku prevádzky, ktorý je najpočetnejší, vykonávajúci rôzne profesie, a to na rôznych funkčných pozíciách podl'a organizačnej štruktúry spoločnosti (tab. 1). Dotazník obsahoval 25 otázok a jeho vyplñnanie trvalo cса. 25 - 30 minút. Celkom bolo plne vyplnených a odovzdaných 749 dotazníkov, čo predstavuje 32,6 \% návratnost'. Jednotliví respondenti zostali vanonymite, čím bola zabezpečená čo najväčšia otvorenost' a úprimnost' respondentov.

Tab. 1: Rozvrstvenie zamestnancov v rámci kvantitatívneho prieskumu

$\begin{array}{llll}\text { úsek financií a správy majetku } & 14,44 & \% \\ \text { úsek l'udských zdrojov } & 8,67 & \% \\ \text { úsek prevádzky } & 55,56 & \% \\ \text { úsek informačných technológií } & 4,68 & \% \\ \text { úsek obchodu a marketingu } & 9,32 & \% \\ \text { úsek generálneho riaditel'a } & 7,33 & \%\end{array}$

Dotazník bol štruktúrovaný do týchto tematických oblastí:

- všeobecné hodnotenie internej komunikácie, komunikačných kanálov, informačných tokov;

- komunikácia na oddelení alebo v inom útvare, komunikácia s nadriadeným;

- priama komunikácia vedenia so zamestnancami, možnosti spätnej väzby zamestnancov;

- komunikácia medzi organizačnými zložkami a medzi jednotlivými skupinami zamestnancov;

- komunikačné nástroje - miera ich využívania, efektivita, námety, nové komunikačné nástroje;

- celková nálada v spoločnosti.

Dotazníkový prieskum ukázal, že interná komunikácia vo vybranom poštovom podniku je jedným z faktorov ovplyvňujúcich motiváciu zamestnancov, ako aj ich postoj voči spoločnosti ako takej.

Čo sa týka všeobecného hodnotenia internej komunikácie, informácie o chode a dianí v pošte, prebiehajúcich a chystaných zmenách, smerovaní pošty a plánoch do budúcnosti získavajú zamestnanci najmä prostredníctvom interných dokumentov a od priameho nadriadeného. Zamestnanci pocit’ujú, že sú pomerne málo informovaní o zmenách, ktoré sa chystajú, o plánoch do budúcnosti a kam chce pošta smerovat' - najmä s ohl'adom na zachovanie ich pracovných miest a ich ohodnotenie. Ako bolo spomenuté, prevažná väčšina respondentov získava informácie prostredníctvom priameho nadriadeného alebo z interných dokumentov. Najmenej zamestnancov označilo ako zdroj informácií intranet a médiá. Úroveň internej komunikácie môže podl'a zamestnancov najviac ovplyvnit' vedenie spoločnosti spolu s priamym nadriadeným.

V oblasti komunikácie nadriadeného s vedením a s podriadenými výsledky boli v celku pozitívne: 
- $\quad$ 75,7 \% respondentov uvádza, že priamy nadriadený dostatočne komunikuje s vedením o potrebách a riadení ich oddelenia;

- $72 \%$ respondentov uvádza, že od svojho nadriadeného získavajú dostatočný prehl'ad o chode ich oddelenia a organizačných a personálnych zámeroch týkajúcich sa ich oddelenia;

- $\quad$ 75, 8 \% respondentov uviedlo, že ich nadriadený vytvára dobré podmienky pre ich prácu a je dobrým vedúcim tímu;

- 84,7 \% respondentov považuje vzájomnú komunikáciu so svojim nadriadeným za bezproblémovú;

- $\quad 75,8 \%$ respondentov je presvedčených, že ich priamy nadriadený dostatočne načúva pripomienkam a námetom svojich podriadených.

Pri hodnotení priamej komunikácie vedenia so zamestnancami a možnosti spätnej väzby zamestnancov výsledky boli odlišné. Najvýraznejšie reagovali respondenti pri požiadavke zlepšit’ prenos informácií od vedenia k zamestnancom. Až 85 \% respondentov si myslí, že táto oblast' potrebuje zlepšenie. Nemalé percento respondentov je presvedčených, že by prospelo i zvýšenie efektívnosti porád, väčšia angažovanost' zamestnancov pri stanovovaní ciel’ov a rozhodovaní v rámci oddelenia.

Pokial' sa posunieme na úroveň komunikácie medzi jednotlivými úsekmi, t.j. na vyššiu úroveň ako je komunikácia medzi oddeleniami, hodnotí ju kladne takmer polovica respondentov (51,8 \%). Na druhej strane až 48,2 \% respondentov je s touto komunikáciu nespokojných. Môže to byt' spôsobené tým, že komunikácia medzi úsekmi nie je taká častá na všetkých úrovniach, čo potvrdzuje i otázka o spolupráci a jej dôležitosti s inými úsekmi (najdôležitejšia je podl'a opýtaných práve komunikácia $\mathrm{v}$ rámci úseku). Respondenti hodnotili kladne spoluprácu úsekov pri získavaní informácií, až 79 \% respondentov uviedlo, že získavajú informácie z iných úsekov bez problémov a rýchlo.

Medzi nástroje internej komunikácie, ktoré sú najčastejšie využívané v poštovom podniku, môžeme zahrnút' porady, intranet a časopis pre zamestnancov a E-zvesti. Porada dáva priestor na uplatnenie iniciatívy, dynamiky a aktivity zúčastnených jednotlivcov, čo je s ohl'adom na vel'kost' pošty významným nástrojom internej komunikácie. Nadpolovičná väčšina $(62,5 \%)$ opýtaných si myslí, že kvalita porád ako aj odovzdávanie informácií na nich je vyhovujúca a sú s ňou spokojní. Avšak až 18,8 \% respondentov sa na poradách nezúčastňuje.

Intranet zatial' nepovažujú zamestnanci za častý kanál na získavanie informácií o pošte a jej chode. Až 22,3 \% respondentov k nemu nemá prístup, čo môže naznačovat' potrebu rozširovat' aj d'alej prístup k moderným informačným spôsobom komunikácie pre širšie spektrum zamestnancov. No vzhl'adom na charakter práce niektorých zamestnancov nie je možné očakávat' ani $100 \%$ prístup. Jedna tretina respondentov považuje intranet za spol’ahlivý zdroj, na ktorom nájdu, čo potrebujú, 12,1 \% respondentov považuje informácie za prehl'adné a d'alších 18,8 \% za dostačujúce.

Vnímanie časopisu pre zamestnancov a elektronického časopisu E-zvesti sa rozdelilo na dve názorové skupiny. Väčšia čast' ho považuje za dostačujúci a nájdu v ňom informácie, ktoré ich zaujímajú. No na druhej strane sa nedá prehliadnut' skoro tretina opýtaných, ktorí ho považujú bud' za nudný, so zbytočnost’ami alebo sa k nemu ani nedostanú. Elektronický časopis E-zvesti a reakcie opýtaných sa dajú vnímat' v súvislosti s postojom k intranetu. Rovnako ako k nemu, 22,2 \% respondentov nemá prístup ani k elektronickému časopisu. 
Poslednou skúmanou oblast'ou bola nálada a medzil'udské vzt'ahy na pošte. Celkovú atmosféru v podniku ohodnotili ako výbornú len $3 \%$ respondentov. Väčšina respondentov (46,6 \%) považuje náladu a medzil'udské vzt’ahy na pracovisku za dobré, avšak 7 \% respondentov ju označilo negatívne. Tendenciu vo vývoji nálady v pošte označili zamestnanci za prevažne zhoršujúcu (51,4 \%) až stagnujúcu.

Zamestnanci mali možnost' formou otvorenej otázky navrhnút', čo by sa malo v oblasti internej komunikácie zlepšit'. Najčastejšie poukazovali na zlepšenie informovanosti o chode spoločnosti ako celku. Zamestnancom (hlavne v prevádzke) chýbajú informácie o pošte a o jej vízii do budúcnosti. S tým súvisí aj ich pocit neistoty, strachu o zamestnanie v súčasnom období ekonomickej krízy. To sa následne odráža na ich nespokojnosti, nervozite a vzájomnej rivalite.

Čo sa týka operatívneho riadenia a zabezpečenia bežného chodu pošty, zazneli požiadavky na odovzdávanie presnejších informácií v správnom čase, aby tak zamestnanci mohli plnit' svoje pracovné povinnosti a úlohy kvalitne a mali vytvorený dostatočný priestor na naštudovanie dokumentov týkajúcich sa danej problematiky.

A ako už bolo spomínané vyššie, zamestnancom chýba spätná väzba, ktorá sa prejavila hlavne v nedostatočnom kontakte vedenia spoločnosti s bežnými zamestnancami. Nechýbali ani požiadavky týkajúce sa celoplošnej dostupnosti a kvalitného vybavenia informačnými a komunikačnými technológiami.

\section{Záver}

Ciel'om organizácií pôsobiacich na slovenskom trhu by malo byt' vytváranie vhodných podmienok na budovanie a efektívne využívanie internej komunikácie, pretože podl'a slov Martina Onofreja (founder of AICO): „Všetko závisí nielen od úrovne internej komunikácie, ale aj od reálnej podpory manažmentu, efektivity change manažmentu, kvality vzdelávania, vyspelosti IT stratégie a d'alšich funkčných oblastí podniku. "

\section{Literatúra}

[1] LEPILOVÁ, K.: Přesvědčivá komunikace manažera, Computer Press, a.s., Brno, 2008, 208 str., ISBN 978-80-251-2147-4

[2] VYMĚTAL, J.: Průvodce úspěšnou komunikací. Efektivní komunikace v praxi, Grada Publishing, Praha, 2008, 322 str., ISBN 978-80-247-2614-4

[3] http://www.amic.sk/nase-sluzby/interna-komunikacia

[4] http://www.aico.sk/sk/novinky/strategic-communication-management-summit-2012londyn

[5] http://karierainfo.zoznam.sk/cl/1000160/1325016/Interna-komunikacia-na-Slovensku-jev-plienkach

\section{Grantová podpora}

VEGA 1/0421/12 Modelovanie difúzie znalostí v podnikových hodnotových ret'azcoch VEGA 1/0895/13 Výskum strategického riadenia podnikov ako podpora konkurencieschopnosti v dynamickom podnikatel'skom prostredí 